\title{
Towards Water Sensitive City: Lesson Learned From Bogor Flood Hazard in 2017
}

\author{
Muhammad Ramdhan ${ }^{1, *}$, Hadi Susilo Arifin², Yuli Suharnoto ${ }^{3}$, Suria Darma Tarigan ${ }^{4}$ \\ 1Doctoral Program of Environmental Management, School of Postgraduate Studies, Bogor Agricultural University, Bogor - Indonesia \\ ${ }^{2}$ Department of Landscape Architecture, Bogor Agricultural University, Bogor - Indonesia \\ ${ }^{3}$ Department of Civil and Environmental, Bogor Agricultural University, Bogor - Indonesia \\ ${ }^{4}$ Department of Soil And Land Resources, Bogor Agricultural University, Bogor - Indonesia
}

\begin{abstract}
Bogor known as rain city and it's located at an altitude range of 190-330 meters above sea level. In February 2017 Bogor experienced a series of natural disasters related to heavy rainfall that fell during that time. The hazard in the form of flash floods that cause casualties was shocked, due to the location of Bogor city that located in the foothills with a fairly steep slope. There is a problem with the drainage system in the city of Bogor. Australia Indonesia Center in cooperation with Bogor city government held a focus group discussion to seek a permanent solution for the problems and so that similar incidents do not occur in the future.
\end{abstract}

\section{Introduction}

Bogor city is one of Indonesia's important and historical cities. Geographically Bogor City lies in the coordinate range of $106^{\circ} 43$ '59.2 "E - $106^{\circ} 50^{\prime} 54.8^{\prime \prime} \mathrm{E} ; 6^{\circ} 30$ '38.6 "S - 6 $6^{\circ} 40^{\prime} 48.5^{\prime \prime} \mathrm{S}$, with an altitude range of 190-330 meters above sea level. It is important, because in Bogor city lay a presidential palace that is often used for visits of state guests. Historic because it has stood since the $15^{\text {th }}$ century as the center of the Pajajaran Kingdom and became a city of rest for the officials in a Colonial era [1]. Bogor in Sundanese language means palm tree root [2], it illustrates that in the past the landscape of Bogor City is naturally overgrown with palm trees. The climate condition of the city of Bogor that known well as the rain city, with the topography of steep terrain, is perfect for the growth of water absorbing trees such as palm trees $[3,4]$. Palm trees will store water in their stems in the wet season and will release them through roots in the dry season, a natural mechanism that benefits the sustainability of water resources.

Development of Bogor City requires a change of land cover. Natural vegetation land is increasingly reduced in number, converted to built up area $[5,6]$ as shown on figure 1 . The coefficient of rainwater runoff on built land is greater than open or vegetated so the ability of the land to absorb water becomes lower [7]. This causes the city of Bogor experiencing problems water flooding in the rainy season, and the difficulty of clean water in the dry season.

In February 2017 there has been an event that shocked the citizen of Bogor. Flash floods occurred in Bogor, with two deaths [8]. This raised a question for the academics, what is the cause of that disaster. This paper will try to provide an overview of the causes of flooding, then looking for a solution for handling it from the perspective of urban water management.

This paper will explores the problem that happen in Bogor City and its surrounding. Regarding the flood event that happened on February 2017.

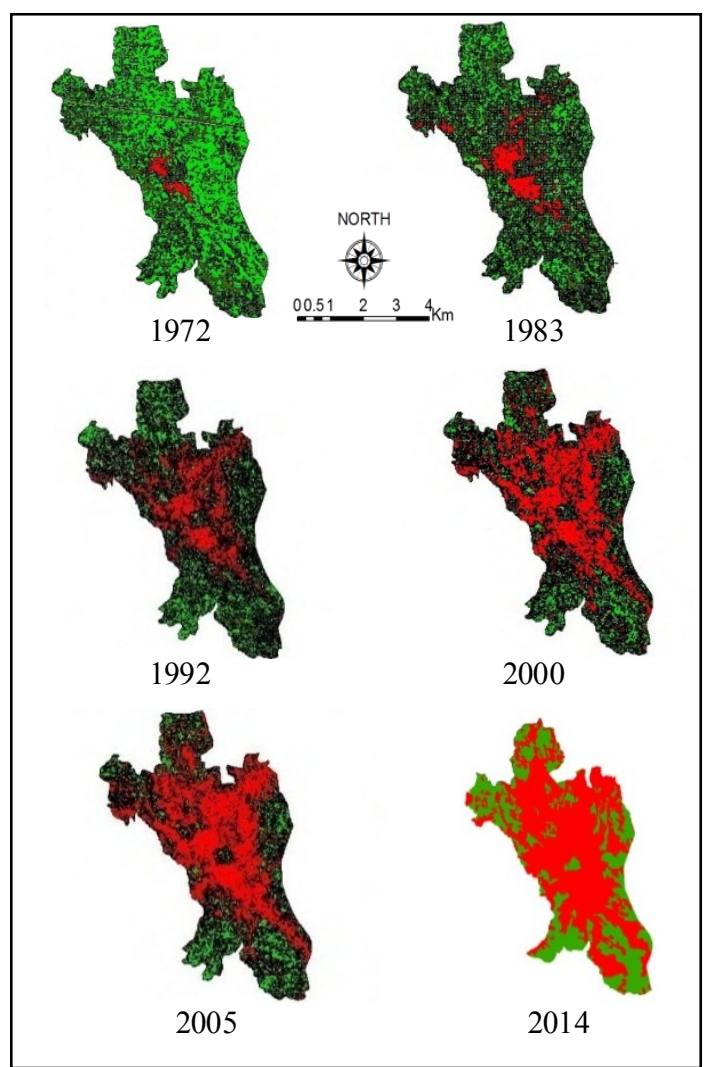

Fig. 1. Urban sprawl in Bogor City; Red is built area, Green is vegetation or open space. 


\section{Methods}

Urban flooding is a complex system, with a rainfall as one of the component on it [9]. We try to find a rainfall event on the date that the flooding event occurred in Bogor city. Then we will examine about the infrastructure for the drainage system in Bogor city. After that we search the literature on the Google scholar about the state the art of urban water management for looking a solution that can be implemented to reduce a flooding event in Bogor city.

The rainfall data recorded by Agency of Meteorological Climatology and Geophysics (BMKG) in Darmaga weather station. Its provide a daily records of rainfall event in Bogor city. We also use the Tropical Rainfall Measuring Mission (TRMM) data that recorded by JAXA-NASA using satellite imagery.

The flood was occurred on February 27th, 2017. at 15.00 West Part Indonesian time zone. It happened after more than 2 hour rain event at Bogor area.

\section{Result}

\subsection{Rainfall event}

From the BMKG weather station in Darmaga-Bogor, we find the hourly data that shows maximum rainfall that occurred in Bogor with in a period of every 2, 5, 10, 20 and 50 years. As shown by Table 1 . Bogor city in every 2 year have a maximum rainfall of $97,6 \mathrm{~mm}$ with the 2 hours duration of the rain .

Table 1. Bogor rainfall event

\begin{tabular}{|c|c|c|c|c|c|}
\hline $\begin{array}{c}\text { Re- } \\
\text { period } \\
\text { (year) }\end{array}$ & $\begin{array}{c}\text { 1- } \\
\text { hrs }\end{array}$ & $\begin{array}{c}\mathbf{2 -} \\
\text { hrs }\end{array}$ & $\begin{array}{c}\mathbf{3 -} \\
\text { hrs }\end{array}$ & $\begin{array}{c}\text { 6- } \\
\text { hrs }\end{array}$ & $\begin{array}{c}\text { 12- } \\
\text { hrs }\end{array}$ \\
\hline 2 & 80.6 & 97.6 & 108 & 115 & 118.8 \\
\hline 5 & 89.4 & 115 & 129 & 139 & 141.1 \\
\hline 10 & 95.2 & 126 & 142 & 154 & 155.9 \\
\hline 20 & 101 & 137 & 155 & 169 & 170 \\
\hline 50 & 108 & 151 & 172 & 188 & 188.3 \\
\hline
\end{tabular}

Source : BMKG Darmaga-Bogor

It was confirmed by TRMM data that on February 27 th, 2017 in southern part of Bogor region heavy rain was happened for more than 3 hours. It shown by the precipitation number value of $23,3 \mathrm{~mm} /$ hour. It is not a maximum value as shown by 2 -hrs re-period in 2 year for Bogor area as reported by BMKG. But still it will send very huge amount of water to Bogor city. Due to the area that the rain was very large as shown on figure 2. In a simple equation we could calculate the amount of water per $\mathrm{Km}^{2}$. With the rainfall of $1 \mathrm{~mm}$, it will give a volume of $1 \mathrm{~mm} \times 1 \mathrm{~km}^{2}=10^{-3} \times 10^{6} \mathrm{~m}^{3}=1000 \mathrm{~m}^{3}$ of water. Bogor area is $118.50 \mathrm{Km}^{2}$. And in the TRMM data we can see that the rain was happen not only in Bogor area but almost all part of southern west java had the rain event at that time.

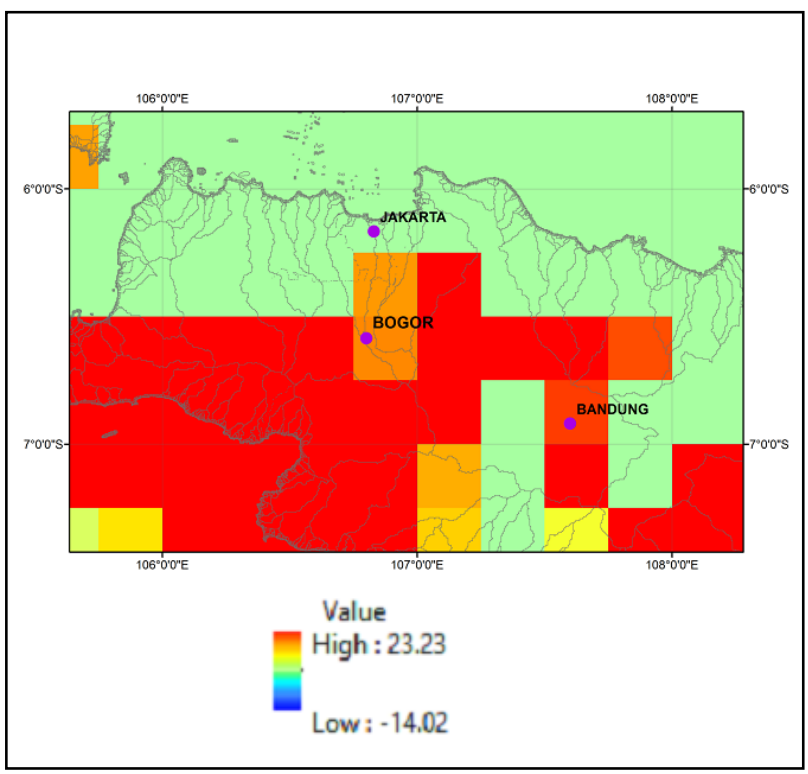

Fig. 2. TRMM data for Bogor region at February 27th, 2017.

\subsection{Irrigation system versus drainage system}

Bogor was an agricultural area which has many paddy fields and the centre of rubber plant in Indonesia. In the Dutch colonial era, the government built an irrigation system to distribute the water to the planting area. Such as in figure 3, The water gate was built at $1872 \mathrm{BC}$ in Empang-Bogor to irrigate more than $4000 \mathrm{Ha}$ paddy fields. But right now the paddy fields has been converted to settlement area.

The irrigation system is used by the developer of the settlement area as a drainage system. There is a different purpose of irrigation system and drainage system. Irrigation purpose is to distribute water, so it has structure from large canals to small canal. In drainage system, the purpose is to throw the water to the larger canals so it will prevent the settlement to get flooded.

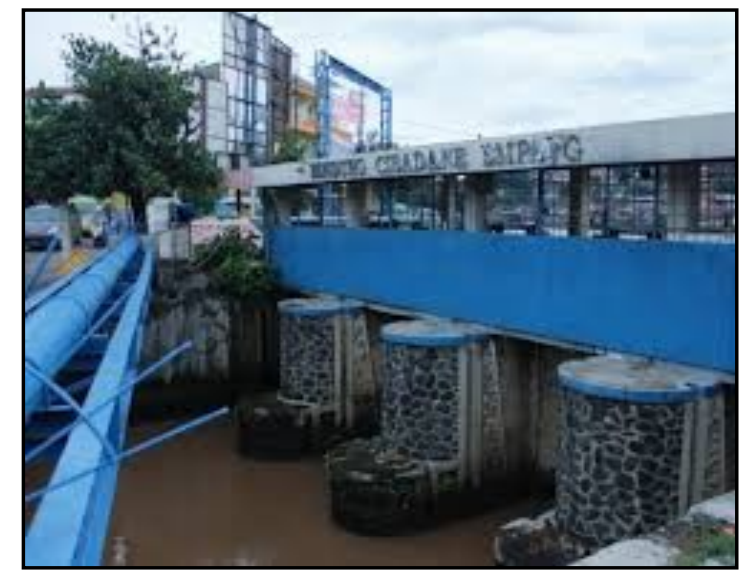

Fig. 3. Water gate for irrigation system in Empang, Bogor 


\subsection{State the art of urban water management}

To find a state of art in the urban water management, we conduct a literature review by using Google Scholar search engine search facility. Google Scholar provides an easy way to search the broad academic literature [10]. Search results can be: peer-reviewed papers, theses, books, abstracts, and articles, from academic publishers, professional communities, universities, and other academic organizations.

The analysis results on the distribution of literature show that there are 675 scientific publications on "urban water" in the last 20 years $(1997-2017)$. The paper has been cited as 6403 times, with 337 citation / year. As for the h-Index of the search topic is 35 , this means there are 35 papers that minimize at least 35 times.

There is an increase in the number of literature from the first five years (1997-2002) of 58 papers to 181 papers in the second five years $(212 \%)$. This shows that in the second period (2003-2007) many new innovations in the topic "urban water". For the next period it appears to be stabilizing with an average increase of 21 papers per fifth year (Figure 4.).

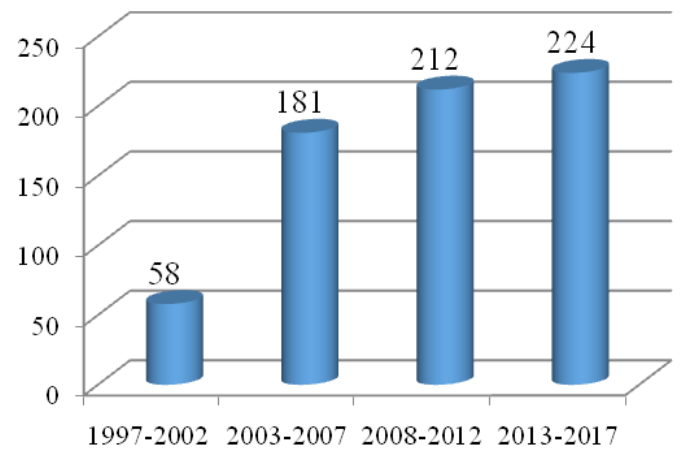

Fig. 4. Number of published literature with the topic of urban water management according to Google scholar
From the 675 publications there are literature that explicitly indicate the location of the study. Australia became the most discussed country as research locus which is found in 90 literatures. While Indonesia is only mentioned in 2 literatures. This shows that research on urban water still needs to be done in Indonesia. And we need to learn from other countries, especially Australia who has discussed many things related to urban water and water sensitive city.

To view more specifically on the themes discussed in urban water research, search results literatures are divided into 10 thematic themes: Management, Engineering, Modeling, Waste, Social, Hydrology, Mitigation, Economics, Climate Change and Conservation. The paper on management topics occupies the most portion of 197 literatures. Followed by a 183 Technique literatures and which is the most rarely discussed topic is the issue of conservation (5 literatures).

\subsection{Water sensitive city}

Water sensitive cities concept arise from the mainstreaming of sustainable development issues. In the early development of a city, population growth will trigger an increase in the need for water, so that the management is to meet the needs of water for its residents. This stage is called "water supply city". The next stage, once the population is met the need for water, it appears the demand for water that is available and that have been used does not have an impact on their health. Then came the "Sewered City" with the management response of providing separate sewerage channels with clean water channels. Furthermore, population growth and development continues to grow causing a city vulnerable to flood disasters. "Drained city" will provide management response for good drainage channels and flood defence.

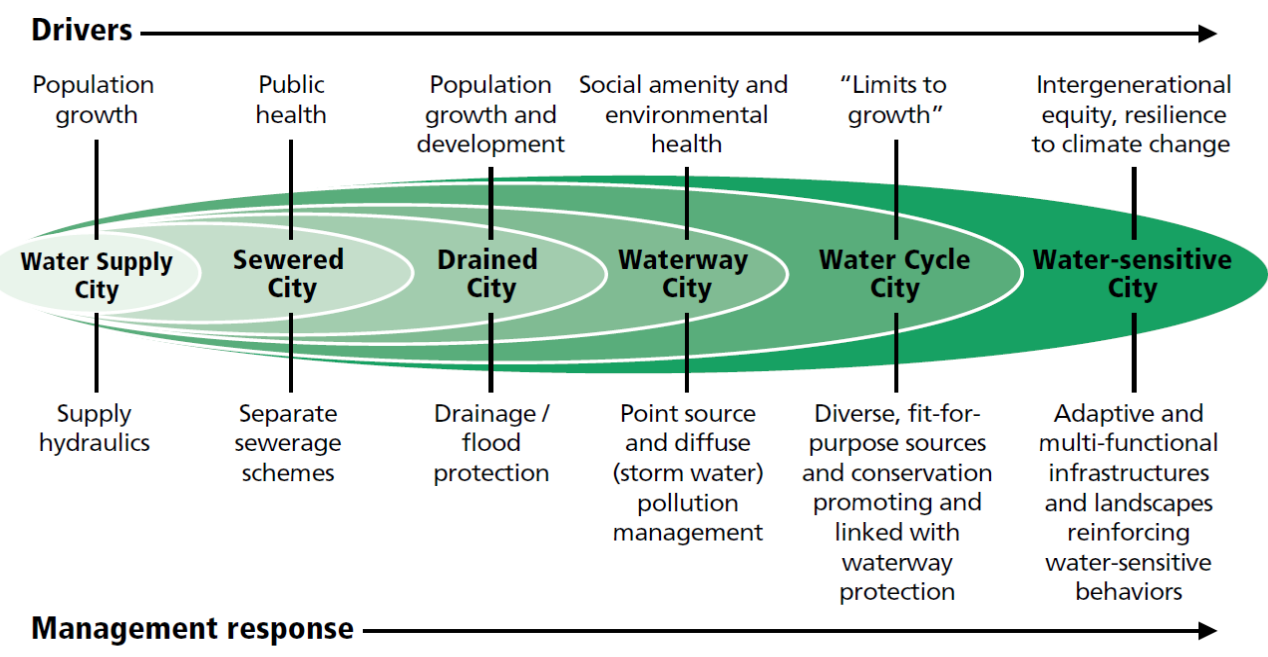

Fig. 5. Urban water management stage [11] 
People who already have a good standard of living are increasingly demanding for the comfort and health of the environment, "waterway city" comes with response to waste handling and the use of more water resources such as the utilization of rainwater runoff. Furthermore, urban communities will have an awareness that the city has a capacity limit and environmental carrying capacity, forming a "watercycle city" that handles urban water resources with new regulations on the use of suitable forsource resources, for example the use of waste water Rinse for flush toilets, and also promote the conservation of protection against the water cycle. Finally, water sensitive city, driven by the spirit of sustainable development that demands intergenerational equality in water resources utilization, is also encouraged by the desire to better adapt to climate change. Water sensitive cities implement adaptive water resource management policies, provision of multifunctional infrastructure and urban landscape arrangement that takes into account the cycles and properties of water (Figure 5).

Centre for Water Sensitive Cities defines the watersensitive city as "a flexible philosophical foundation in the provision and use of water resources to meet all user needs related to the collection and movement of water, may be a technology to facilitate the physical movement of water by a design that recognizes and appreciates the visual appearance of water".

\section{Discussions}

\subsection{What really happened during the hazard}

High rainfall level in the southern region of Bogor city triggers the occurrence of flash flood. This can be seen from the results of TRMM data analysis that provides an overview of precipitation condition when incident is happened, February 27, 2017. Although the rainfall that occurs is not the maximum value of the annual cycle as it is recorded from BMKG station. However, high rainfall in the upstream area will increase the probability of flash flood events [12].

It is getting worse by the condition of urban drainage infrastructure in the Bogor city. Because it using the former irrigation channels as drainage channels. Interesting facts found in the field that on irrigation channels that flow into the location of flash flood, found many channels that have been closed and switch functions to become built area.

\subsection{Who should be responsible?}

Government as the first actor who make the spatial planning and flood risk management policies and practices (including their coordination capacity) got to take a responsibility to protect it territory from such a disaster [13]. Academia as the intellectual actor should be involved to give the best solution according the latest science and technology. The research about urban water in Bogor city must be prioritize.

Businessman or private sector, as the one who get economical profit for their business in Bogor city. They should care to the water issue. Because they are the actor who spend most of the water supply in many place. Community or the people who live in Bogor area should be involve also, they are the actor and a victim of the unwell planed urban water system in Bogor city. Community action will be more effectively give a direct impact in the field, the media, they are the one whose responsible to give a right information to the people. They can be a leading actor to make an issues become interesting and mainstream for the daily live of the people.

\subsection{Towards water sensitive city in Bogor}

Bogor City need to be change and do a transformation in management the water in its territory. To overcome the same case will be happened again in the future. The success story of Melbourne city [14] can be implemented here. The outcome is not from a blueprint plan and a topdown management process, but of a strategic steering process of transition navigation over a long period of time. It seems that as long as there is a small group of normatively aligned, loosely connected lead actors from a range of sectors across the niche and regime levels, who are committed to long-term change and are supported by strategic, responsive bridging organizations, which collectively embrace a collaborative, learning-by-doing approach, then the shape, direction and speed of a transition may be influenced.

The role of frontrunners was critical in encouraging and guiding the transition through disrupting old and creating new institutional routines, it was the dynamic interplay between the frontrunners and the creation (and modification) of institutional structuring features and processes that has provided the vehicle for shaping the transition.

Overall, the actor-dynamics in Melbourne suggest that in order to enable and influence a sustainability transition, key actors need to be involved in designing, generating and connecting (shadow) actor networks and relevant bridging organizations, which reflect the stage and sophistication of niche development, while collectively promoting a collaborative learning environment. To exert the necessary influence on the regime, bridging organizations should first focus on generating understanding, collating evidence and nurturing relationships, then build confidence amongst practitioners, up-skill and train a broad range of actors within the sector, then focus pressure towards generating policy shifts. Based on the polycentric institutional design and the patterns of institutional work used by key individual and organizational actors, and the emergence and purpose of bridging organizations, policy makers and urban water strategists may be able to identify 
critical leadership deficits and possible disrupting and creating strategies so they can target their work to shape a more enabling platform for change. Ultimately, no one component will be responsible for influencing the pathway of a transition.

\section{Conclusion}

The flooding hazard that happen in Bogor city at February 2017 was a combination of flash floods that come from intensive rainfall on the southern part of Bogor, and also the poorness of local urban water management condition due to loss of water retention area /water parking lot and the unfit function of using irrigation system as a drainage system.

Bogor city must adjust the existing channel condition from the original as irrigation infrastructure become the current requirement for Bogor city become urban drainage system. Urban drainage channels need to be built according to existing urban infrastructure conditions to accommodate an abundance of rainwater that exceeds river flow capacity, which will address flood disasters as a whole, integrated, and environmentally friendly. This adjustment could provides an opportunity for the availability of raw water sources for urban clean water from previously provided for agricultural irrigation of 4000 liters /s.

To achieve a water sensitive city level. Bogor city must have a long term planning to get all stake holder sit together and collectively embrace a collaborative, learning-by-doing approach. Bidging organizations should first focus on generating understanding, collating evidence and nurturing relationships, then build confidence amongst practitioners, up-skill and train a broad range of actors within the sector, then focus pressure towards generating policy shifts.

\section{Acknowledgement}

The writer want to thank you to Australia Indonesia Centre who give an opportunity for Bogor city as one of case study for the development of water sensitive city in south east Asia. Also for the rector of Bogor Agriculture University who give all facility during study literature and discuss. For the ministry of marine and fisheries affairs who giving a scholarship program.

\section{References}

1. Jatmiko, P. Sejarah Kota Bogor. Karta Nagari. Bogor : Karya Cipta Anak Negeri. (2015)

2. S. Danasasmita, Sejarah Bogor - Volume I. Bogor: Pemerintah Daerah Kotamadya DT II Bogor. (1983)

3. S. N. Ichwani, Skripsi. Departemen Konservasi Sumberdaya Hutan Dan Ekowisata. Fakultas Kehutanan. Institut Pertanian Bogor. Bogor. (2013)

4. D. Saputra, Diploma thesis, Universitas Andalas. Padang. (2013)

5. Arkham, H. S. Arifin, R. L. Kaswanto, N. H. S. Arifin, Prosiding Lokakarya Nasional dan Seminar Forum Komunikasi Perguruan Tinggi Pertanian Indonesia. Bogor: Institut Pertanian Bogor. (2013)

6. E. F. Irianti, Skripsi. Program Studi Arsitektur Lanskap. Fakultas Pertanian. Institut Pertanian Bogor. Bogor. (2008)

7. K. W. F. Howard, R. G. Israfilov. Canada: Kluwer Academic Publishers. Springer-Science Business Media. (2002)

8. http://megapolitan.kompas.com/read/2017/03/01/20 583781/banjir.di.bogor.terjadi.di.kawasan.rentan. accesed on June 12th 2017.

9. Chang L. Huang S. Landscape and Urban Planning J. E.143, 13 (2015)

10. N. K. Susrini, Google: Mesin Pencari yang Ditakuti Raksasa Microsoft, Book. Mizan, B-first, 264 page. (2009)

11. T. H. F. Wong, R. R. Brown, Water Science \& Technology. IWA Publishing. Melbourne-VIC. (2009)

12. D. Audrey, R. Hélène, G. Pierre-André, L. Kévin, L. David, D. Denis, Journal of Hydrology 541 (2016)

13. F. Maria, D. Marcin, T. Yuting, C. Faith, S. Dominic, Progress in Planning 114 (2017)

14. R.R. Brown et al., Global Environmental Change 23 (2013) 